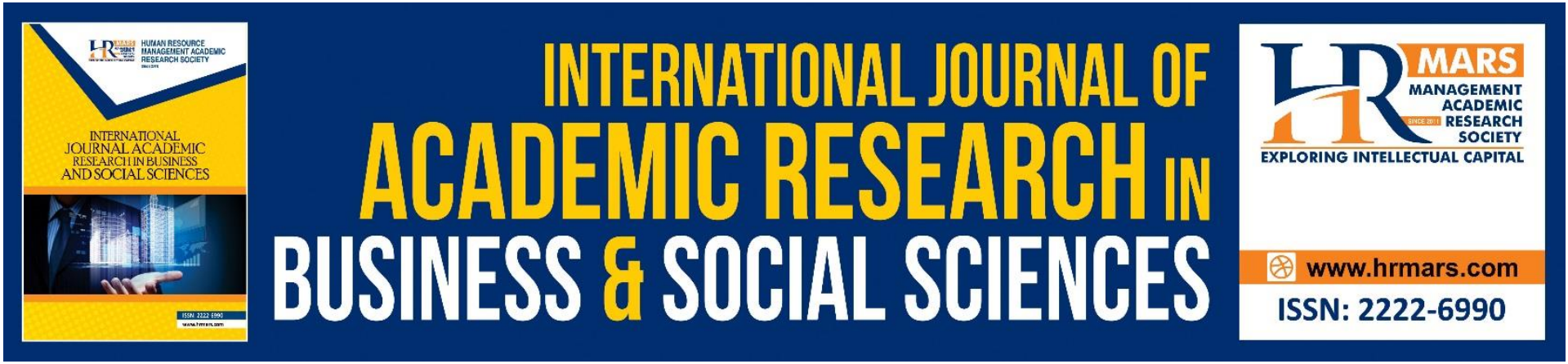

\title{
A Preliminary Study of Factors Influencing on Employee Performance
}

Siti Nur Zahirah Omar, Che Mohd Syaharuddin Che Cob, Siti Rosnita Sakarji, Ayu Kamareenna Abdulllah Thani, Azizi Abu Bakar

To Link this Article: http://dx.doi.org/10.6007/IJARBSS/v12-i1/12234 DOI:10.6007/IJARBSS/v12-i1/12234

Received: 12 November 2021, Revised: 14 December 2021, Accepted: 29 December 2021

Published Online: 19 January 2022

In-Text Citation: (Omar et al., 2022)

To Cite this Article: Omar, S. N. Z., Cob, C. M. S. C., Sakarji, S. R., Thani, A. K. A., \& Bakar, A. A. (2022). A Preliminary Study of Factors Influencing on Employee Performance. International Journal of Academic Research in Business and Social Sciences, 12(1), 1880-1891.

Copyright: @ 2022 The Author(s)

Published by Human Resource Management Academic Research Society (www.hrmars.com)

This article is published under the Creative Commons Attribution (CC BY 4.0) license. Anyone may reproduce, distribute, translate and create derivative works of this article (for both commercial and non0-commercial purposes), subject to full attribution to the original publication and authors. The full terms of this license may be seen at: http://creativecommons.org/licences/by/4.0/legalcode

Vol. 12, No. 1, 2022, Pg. 1880- 1891

Full Terms \& Conditions of access and use can be found at http://hrmars.com/index.php/pages/detail/publication-ethics 


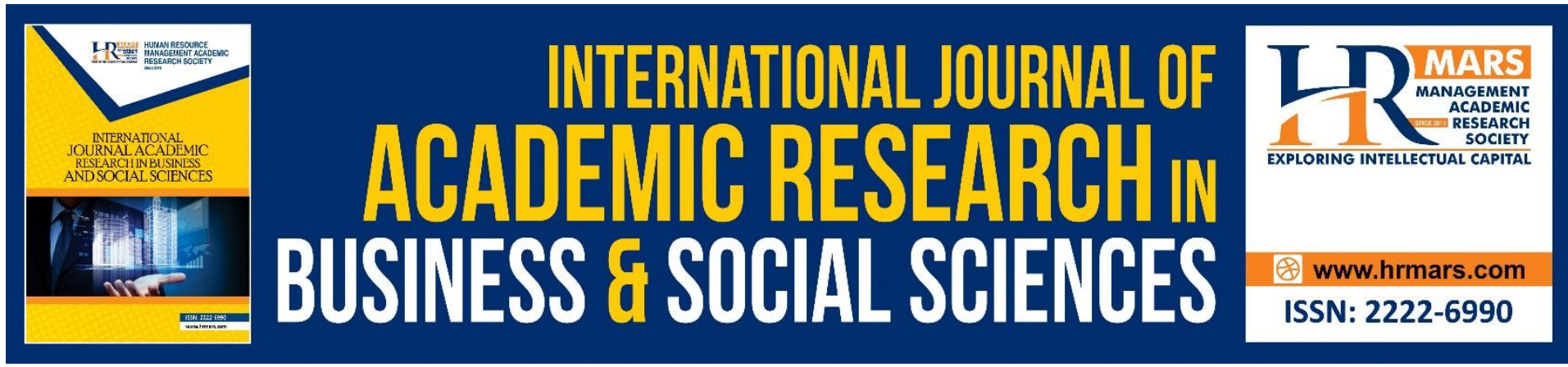

\title{
A Preliminary Study of Factors Influencing on Employee Performance
}

\author{
'Siti Nur Zahirah Omar, ${ }^{2} \mathrm{Che}$ Mohd Syaharuddin Che Cob, ${ }^{3}$ Siti \\ Rosnita Sakarji, ${ }^{4}$ Ayu Kamareenna Abdulllah Thani, ${ }^{5} \mathrm{Azizi}$ Abu \\ Bakar \\ ${ }^{1234}$ Faculty of Business and Management, Machang Campus, Universiti Teknologi MARA, \\ Cawangan Kelantan, ${ }^{5}$ Universiti Utara Malaysia, Sintok, Kedah \\ Email: 'sitinurzahirah@uitm.edu.my, ${ }^{2}$ syaha793@uitm.edu.my, ${ }^{3}$ rosnita507@uitm.edu.my, \\ 4ayukamareenna@uitm.edu.my, 5abazizi@uum.edu.my
}

\begin{abstract}
An organisation is frequently stated to be only as good as its human capital, which means that people are important to the firm's success. The achievement of organizational goals is a critical component of employee success. As a result, the organisation requires capable people. When people do not perform successfully, it has an effect on their performance and the organization's overall success. Thus, the purpose of this study is to determine the factors that influence an employee's performance. Three independent variables affecting employee performance are identified based on an extensive literature analysis and the Job DemandControl-Support (JDCS) model. They are time pressure, lack of motivation, and heavy workload. As a result, the research model was suggested. A pilot study was undertaken among academics at Universiti Teknologi MARA, Kelantan campus. The details of the factors contributing to an employee's performance were described using descriptive statistics. The results of this study will be utilized to improve the instrument, which will then be used to collect data from a wider pool of respondents.
\end{abstract}

Keywords: Employees' Performance, Time Pressure, Lack of Motivation, Heavy Workload.

\section{Introduction}

Employee performance has continuously gained huge attention since a few decades ago and is frequently highlighted in society. According to Silitonga and Sadeli (2020), employee performance is frequently interpreted as representative of the organization's performance and has a direct impact on the organization's image. Khan and Mashikhi (2017) stated that performance has been considered as the ultimate outcome of an organization as well as an employee. Creativity, innovation, and a higher level of commitment among employees are the sources of organizational success and glory. A study by Prange and Pinho (2017) mentioned that, since human resources are an important factor in any organization, organizational productivity and efficiency depend on the performance of its employees. The survival of the organization will depend on their ability to provide the employees with the necessary actions. Enhanced capabilities, knowledge, and skills are the foundation for the 
organization's competitive advantage in today's global market (Rodriguez \& Walters, 2017). Managers of organisations should consider meeting employees' mental and physical requirements and enhancing employees' personal and occupational performance using a variety of means and methods, such as training, performance review, and job design (Abdulkhaliq \& Mohammadali, 2019).

Malaysia's Ministry of Human Resources spent around RM455,025 million on human capital development between 2019 and 2020. As a result, a critical part of Malaysia's human capital development is the requirement for employees to adapt to new knowledge and improve their job performance. According to the Public Service Department Circular (2006), the government's policy is to provide a minimum of seven training days per year to all employees, including those who work at institutions of higher. This will help them be capable of performing their job. As per the policy imposed by the University of Technology MARA (UiTM), its employees must attend a minimum of 42 hours of training per year to increase their knowledge, skills, and abilities (KSAs) even during the COVID-19 pandemic that has spread widely throughout Malaysia. These reflect that there is continuous concern about employees' quality and performance among the top management.

However, in the local context, despite the government's investment in their training and development, numerous grievances and complaints have been lodged against public sector employees for their effectiveness and inefficiency. For instance, in 2019, Malaysia received 4,939 complaints against public sector employees, of which 94 were directed to the Higher Education Ministry (Biro Pengaduan Awam, 2019). The literature demonstrates that numerous variables disrupt employee work, including the impact of the physical workplace on employee performance and job completion, as well as the intention to leave (Hoboubi et al., 2017). When the physical environment of the office is good, it positively impacts on the employees' desire to acquire more skills and their level of enthusiasm towards work (Al-Omari \& Okasheh, 2017). Similarly, a poor work environment can contribute to staff dissatisfaction with their jobs (Hoboubi et al., 2017). On the other hand, Khan and Mashikhi (2017) emphasise the importance of teamwork in enhancing individual performance and fostering a positive work environment for employees. Khair (2017) believes that to achieve higher performance, the company needs to provide appropriate compensation to its employees, as it will encourage awareness of employees to work better and follow the rules of the company. Although numerous studies have been conducted on employee performance, it appears as though organisational leaders continue to face gaps and obstacles in this area. Thus, this study aims to ascertain the elements affecting academicians' performance at Universiti Teknologi MARA, Kelantan Campus.

\section{Literature Review \\ Employee Performance}

Performance is a metric used by successful businesses to measure their work accomplishments. Experts define performance as the outcome of a person's work or the performance of a person's work in carrying out his or her tasks and responsibilities (Rusmiati \& Fitriani, 2021). Meanwhile, employee performance is a metric that indicates how well employees adhere to both explicit and implicit standards, objectives, and priorities. Employee performance is defined as the manner in which employees complete their assigned work and perform required responsibilities (Omar, 2010). Additionally, it refers to the effectiveness, quality, and efficiency of manufacturing. Productivity also has an effect on how employees perceive their value to the organisation. Employee performance is also critical to a business's 
success. Each employee must work diligently to ensure that the company's vision and goal are realised (Bakar, 2018).

The level of productivity of the workforce is one of the elements that can be measured. Several studies have introduced several ways for assessing organisational performance (Wong \& Wong, 2007; Prajogo, 2007). This comprises the individual's quality, quantity, knowledge, or inventiveness toward completed activities that are in compliance with the obligation throughout a given period. In other words, evaluation systems must have some standard parameters that can be depended upon. In line with what Basit (2017) stated, employee performance are the actions taken by workers to perform the work assigned to them by the company. Taking on one's own obligations is never self-sufficient; it is always contingent on the employee's pleasure with the job, the amount of compensation, as well as personal abilities, skills, and personality qualities.

\section{Factors Influencing with Employee Performance Time Pressure}

Time is an extremely valuable commodity. Time pressure is one of the most difficult and important factors affecting employee performance. Time pressure is described as a person's perception of their capacity to finish a task within a set time restriction; it explains that task completion on time shows task effectiveness and efficiency (Johari et al., 2019). Time constraints, however, are imposed. Time pressure can affect everything from simple math tasks (Bryan \& Locke, 1967) to aeroplane piloting (Raby \& Wickens, 1994).

The impacts of time pressure on performance are mostly due to cognitive capacity restrictions (Johari et al., 2019). People have limited cognitive and attentional resources (Sijbom et al., 2018), and each task necessitates a series of decisions about how to distribute those resources. When time is limited, people are more prone to employing heuristic processing procedures (also known as "mental shortcuts") rather than slower, more deliberate cognitive processing. One disadvantage of employing heuristics is that, in comparison to slower cognitive processing processes, heuristic processing is more prone to biases and systematic errors (Wirth et al., 2017). When people are under time constraints, for example, they tend to demonstrate larger primacy effects, focusing too much on whatever they learn first (Ryari et al., 2021). People who are pressed for time are more prone to judge others based on preconceptions and are also more susceptible to anchoring biases (Leroy \& Glomb, 2018). Even choosing between decision-making techniques consumes cognitive resources, and time pressure diminishes the desire to change previous decision-making patterns in order to adapt to tasks that require new answers. Final deadlines, in general, reduce the time available to conduct a thorough search for alternative solutions, favouring well-learned, uncomplicated, or routinized activities.

The impact of time pressure on worker performance has yielded unexpected results. Time pressure has a negative impact on performance, according to a study by Baethge et al. (2019). Broberg et al (2017), for example, found the same outcome of time pressure having a detrimental impact on employee performance. Wijaya and Yulyona (2017), on the other hand, discovered that there is no link between employee performance and time pressure.

\section{Lack of Motivation}

Motivation is a mechanism that allows someone to work toward their objectives, and it is a form of intelligence that is not readily visible (Ibrahim and Brobbey, 2015). The importance of employee motivation cannot be overstated. In reality, it is one of the most crucial and critical 
components in ensuring employee success and, eventually, the attainment of company aims and goals (Berman et al., 2010). Furthermore, employee motivation is an important component of corporate operations, since high motivation is associated with job satisfaction, a sense of pride in one's work, and a long-term commitment to the organisation, all of which improve performance and productivity (Linz et al., 2006).

Employees who are highly driven are a long-term value to an organization's success. Many employers face a major issue in effectively motivating their personnel. Previous research has identified a number of potential methods and strategies via which managers might influence employee motivation and consequently increase employee performance. According to Kamery (2004), motivated employees are those who exhibit behaviours such as self-satisfaction, sales fulfilment, and commitment, all of which are expected to create higherquality work and adhere to the organization's regulations, resulting in significant efficiencies and competitive advantage. Employee motivation boosts job involvement by making work more relevant and engaging, as well as keeping employees more productive and improving their subsequent job performance (Ekerman, 2006).

\section{Heavy Workload}

Workload management refers to how a person manages his or her ability to do his or her job, whether it's physical ability, cognitive ability, or the ability to bear weight (Rusmiati \& Fitriani, 2021). Physical and mental burdens make up the burden. Lifting, transferring, caring, and pushing are examples of physical workloads. While he is comparing his abilities and work to those of others, his mental workload is increasing (Manuaba, 2000). Meanwhile, according to Wilhelm et al (2008), work overload refers to the amount of work, time spent, and irritation experienced as a result of not being able to accomplish the work within the time frame set. As stated by Shah et al (2003), working lengthy hours, particularly at the expense of other aspects of the job, is not a good idea. The lives of workers add to the workload. In addition to a long period of time, there is a sense that a large amount of work must be finished in a short period of time. It is generally known that the difficulties of high workload and stress at work appear to be increasing on a daily basis, and that every employee, regardless of their background or industry, appears to be affected by this problem.

Workload has a big impact on employee job performance and shouldn't be ignored. According to Ganster and Rosen (2013), unmanageable workloads are reported as a significant stressor by 46 percent of employees. Due to a tremendous workload, employees who have no control over their work may feel burnout. Burnout is defined by the World Health Organization as a type of continuous work stress that depletes energy and reduces effectiveness. 50 percent of employees have left their jobs due to burnout. According to a study by Lam et al. (2010) on the factors that create stress among interns, 90 percent of interns reported that workload and working hours were the main sources of stress.

\section{Relevant Theory and Research Model}

Theory of Job Demands-Control (JDC). The JDC model is a well-known theory that was proposed by Karasek in 1979 to explain the study. The Job Demand-Control Support (JDCS) model is an extension of the JDC model that has been used to gain a better understanding of how job features affect employees' psychological well-being (Karasek \& Theorell, 1990). Among the job requirements are work overload and role conflict. On the other hand, job resources refer to the organisational characteristics of a job that are important for achieving work goals and minimising job demands and their associated negative consequences. 
According to Karasek and Theorell (1990), Vaananen and Toivanen (2018), and Brandtzg, Flstad, and Heim (2018), the JDCS model was established to demonstrate how job demands such as severe workload, role ambiguity, and job-related tension can induce stress for employees.

JDCS is one of the most extensively investigated models of job attributes and employee psychological well-being in the workplace. The JDCS model has been inconsistent (Ganster \& Perrewé, 2011; Crescenzo, 2016 \& Jalilian et al., 2019), with the primary reason mentioned being that the model does not account for employees' qualities. To address these concerns, the proposed study incorporates employee characteristics such as time constraints, a lack of motivation, and a heavy workload into employee performance (Ganster \& Rosen 2013; Ibrahim \& Brobbey 2015; Garbarino \& Magnavita 2015; Francioli et al., 2016; Grover \& Roche, 2017; Johari et al., 2019; and Ryari et al., 2021). The JDCS model's basic premise is that control mitigates the effect of job demands on pressure and can help improve employee performance by providing opportunities for difficult assignments and skill development (Karasek \& Theorell, 1990). When workplace demands are high and employees are under pressure, taking charge of the job and creating good relationships with co-workers and supervisors can help employees cope with stress. Figure 1 illustrates a proposed research model based on the discussion.

Figure 1: Research Model

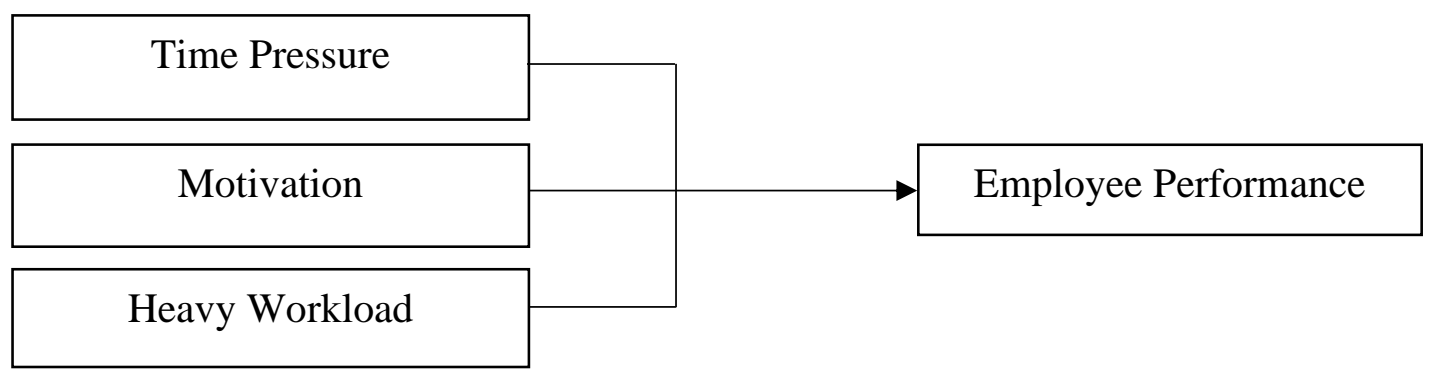

\section{Data Collection and Methodology}

The study's research strategy is based on a quantitative method. Using norms of reliability and validity of statistical techniques, the quantitative approach is suited for deductive research, objective, and outcome-oriented investigations (Hair et al., 2010; Creswell, 2009). This is a cross-sectional study, in which data is gathered, analysed, and statistically summarised while conclusions are reached at a particular moment in time. This is a pilot research article that focuses on the measurement items' reliability and validity. The goal of a pilot test process is to test the survey questions with a small number of samples in order to determine whether the survey architecture fits the research objective and is clearly understood by respondents. A pilot test is crucial to undertake, according to Kholed et al. (2021), since it helps to establish the dependability and suitability of the data collection in order to process the future research instrument efficiently.

The study's measurement scale was created by using a list of possibly validated items from previous research (Table 1). The categories were operationalized using a five-point Likert scale ( $1=$ strongly disagree to $5=$ =strongly agree) with 20 items measuring respondents' level of agreement on four variables: time pressure, motivation, heavy workload, and employees' performance. This study's empirical data was gathered through a survey method. This study focused on an academician at UiTM Machang and UiTM Kota Bharu. 
Table 1. Summary Table of Instruments

\begin{tabular}{lll}
\hline Construct & Sources & $\begin{array}{l}\text { No. } \\
\text { items }\end{array}$ \\
\hline Employees' Performance & Cai Li et al (2019); Barrada et al (2019) & 5 \\
\hline Time Pressure & Tommy et al (2015); Li-Hwa \& Wenzhi (2013) & 5 \\
\hline Lack of Motivation & $\begin{array}{l}\text { Mohammed et al (2020); Catherine et al (2005); } \\
\text { Linda et al (2014) }\end{array}$ & \\
\hline Heavy Workload & Khalil et al (2015) & 5 \\
\hline
\end{tabular}

The actual data was screened to ensure that the data was accurately input, that there were no missing values, that there were no free outliers, and that the variable distribution was normal. The data was analyzed using SPSS version 23 . The impact of time pressure, lack of motivation, and heavy workload on employee performance was described using descriptive statistical analysis.

\section{Discussion of Findings}

The term 'frequency analysis' refers to the frequency with which distinct subcategories of a phenomena occur, from which the percentage and cumulative percentage of occurrences may be easily determined (Sekaran \& Bougie, 2016). According to Table 2 , this study surveyed 90 respondents. Among these respondents, females made up 65.6 percent of the respondents, while males made up 34.4 percent of the sample. It was revealed that female academics predominate at UiTM Machang and Kota Bharu. Only 6.7 percent of respondents were beyond the age of 50 and above, and 78.9 percent and 14.4 percent were being between the ages of 30-40 and 40-50 years old. In this survey, the majority of respondents (52.2 percent) were married, compared to 47.8 percent who were single. The majority of respondents' monthly income ranged from RM5000 and above (33.3\%), 25.6 percent from RM2001 to RM3000, and 24.4 percent and 10\% from RM1001 to RM2000 and RM3001 to RM4000, respectively.

Meanwhile, only 6.7 percent from the income group of RM4001 to RM5000, which was the lowest of the four income groups, actually made their way into the survey. The academicians at UiTM Machang and UiTM Kota Bharu are the focus of this study. Academicians from UiTM Machang made up the bulk of respondents, 60 percent, while academicians from UiTM Kota Bharu made up the remaining 40 percent. 
Table 2. Profile of respondents

\begin{tabular}{llll}
\hline Category & & $\begin{array}{l}\text { Frequency } \\
(\mathbf{N}=90)\end{array}$ & Percentage \\
\hline Gender & Female & 59 & 65.6 \\
& Male & 31 & 34.4 \\
Age & 30-40 years old & 71 & 78.9 \\
& 40-50 years old & 13 & 14.4 \\
& 50 - above & 6 & 6.7 \\
Marital status & Married & 47 & 52.2 \\
& Single & 43 & 47.8 \\
Income & RM1001 - RM2000 & 22 & 24.4 \\
& RM2001 - RM3000 & 23 & 25.6 \\
& RM3001 - RM4000 & 9 & 10.0 \\
& RM4001 - RM5000 & 6 & 6.7 \\
& RM5000 - above & 30 & 33.3 \\
Staf & UiTM Machang & 54 & 60 \\
& UiTM Kota Bharu & 36 & 40 \\
\hline
\end{tabular}

The most popular technique for assessing reliability, such as the dependability of a measuring scale or internal reliability, is Cronbach's alpha $(\alpha)$ (Nunnally \& Bernstein, 1994; Sekaran \& Bougie, 2016). In the literature, many thresholds have been proposed. The alpha level, according to Nunnally (1978) and Hair et al. (2010), should be 0.7 or higher, implying that a value larger than 0.7 shows that the variables are internally consistent and appropriate measurements for the research. As a result, 0.70 was chosen as the minimal threshold to show the constructs' internal consistency in this study. The findings for all variables in this study ranged from .889 to .966 (Table 3 ). Since all values were larger than 0.7 , they were inside the allowed range, implying that all variables were trustworthy.

Table 3. Descriptive statistics and reliability analysis

\begin{tabular}{llll}
\hline Factors & Mean & SD & Cronbach's Alpha \\
\hline Employees Performance & 4.487 & 0.48626 & .861 \\
Time Pressure & 3.511 & 0.88641 & .868 \\
Lack of Motivation & 2.233 & 1.11184 & .960 \\
Heavy Workload & 3.164 & 0.96341 & .871 \\
\hline
\end{tabular}

\section{Conclusion}

The results of this study show that time pressure, a lack of motivation, and a heavy workload all have an impact on employee performance at UiTM Cawangan Kelantan. Due to various constraints and restrictions, the topic of this study at UiTM Kelantan has received less public attention. Therefore, practically, this study could help the management at UiTM in terms of creating awareness among the academicians about the factors that could influence their work performance. Overall, it is suggested that UITM implement some training programs such as stress management for academicians in order to reduce the level of pressure during peak 
periods and time deadlines. The training programmes should concentrate on how to deal with stress as a result of the difficulties that they may face in their academic job. In return, academicians could directly increase their productivity and be more committed to the organisation since they are able to release their work pressures appropriately. On the other hand, theoretically, this study aids to the researchers by providing recent literature and new analysis which relates to the issue on academician's work performance.

\section{References}

Abdulkhaliq, S. S., \& Mohammadali, Z. M. (2019). The Impact of Job Satisfaction on Employees' Performance: A Case Study of Al Hayat Company-Pepsi Employees in Erbil, Kurdistan Region-Iraq. Management and Economics Review, 4(2), 163-176.

Al-Omari, K., \& Okasheh, H. (2017). The influence of the work environment on job performance: A case study of an engineering company in Jordan. International Journal of Applied Engineering Research.

Anjum, A., Muazzam, A., Manzoor, F., Visvizi, A., Pollock, G., \& Nawaz, R. (2019). Measuring the scale and scope of workplace bullying: An alternative workplace bullying scale. Sustainability, 11(17), 4634.

Bakar, A. A., \& Zahirah Omar, S. N. (2018). Effective Leadership as the Mediator between Emotional Quotient and Teachers' Work Performance: A Study in National Secondary School in Northern States of Peninsular Malaysia. Indian Journal of Public Health Research \& Development, 9(11).

Basit, A., \& Hassan, Z. (2017). Impact of job stress on employee performance. International Journal of Accounting and Business Management, 5(2), 13-33.

Baethge, A., Deci, N., Dettmers, J., \& Rigotti, T. (2019). "Some days won't end ever": Working faster and longer as a boundary condition for challenge versus hindrance effects of time pressure. Journal of occupational health psychology, 24(3), 322.

Berman, E. M., Bowman, J. S., West, J. P., \& Wart, M. R. V. (2010). Motivation: Possible, Probable or Impossible? Human Resource Management in Public Service: Paradoxes, Processes and Problems (pp. 180). California: SAGE Publications, Inc.

Brandtzæg, P. B., Følstad, A., \& Heim, J. (2018). Enjoyment: lessons from Karasek. In Funology 2 (pp. 331-341). Springer, Cham.

Broberg, P., Tagesson, T., Argento, D., Gyllengahm, N., \& Mårtensson, O. (2017). Explaining the influence of time budget pressure on audit quality in Sweden. Journal of Management \& Governance, 21(2), 331-350.

Bryan. J, dan E. A. Locke. 1967. Goal Setting as a Means of Increasing Motivation, The of Applied Psycology, pp: 274-277.

Crescenzo, P. (2016). An ancient theory for a current problem [Review of the book Healthy Work: Stress, productivity and the reconstruction of working life, by RA Karasek \& T. Theorell]. Journal of Health and Social Sciences, 1(3), 287-292.

Creswell, J. W. (2009). Research design: Qualitative, quantitative, and mixed methods approaches ( $3^{\text {rd }}$ edn). California: SAGE Publications Ltd.

Curtis, C. R., Upchurch, R. S., \& Severt, D. E. (2009). Employee motivation and organizational commitment: A comparison of tipped and nontipped restaurant employees. International Journal of Hospitality \& Tourism Administration, 10(3), 253-269.

Ekerman, G. (2006). Job Enrichment and Staff Motivation. Human Resource Management (pp. 183-191). Cape Town: Maskew Miller Longman (Pvt) Ltd. 
Ekienabor, E. E. (2016). Impact of job stress on employees' productivity and commitment. International journal for research in business, management and accounting, 2(5), 124133.

Francioli, L., Høgh, A., Conway, P. M., Costa, G., Karasek, R., \& Hansen, Å. M. (2016). Do personal dispositions affect the relationship between psychosocial working conditions and workplace bullying? Ethics \& Behavior, 26(6), 451-469.

Garbarino, S., \& Magnavita, N. (2015). Work stress and metabolic syndrome in police officers. A prospective study. PloS one, 10(12), e0144318.

Ganster, D. C., \& Perrewé, P. L. (2011). Theories of occupational stress.

Garling, T., Gamble, A., Fors, F., \& Hjerm, M. (2016). Emotional well-being related to time pressure, impediment to goal progress, and stress-related symptoms. Journal of Happiness Studies, 17(5), 1789-1799.

Grover, S. L., Teo, S. T., Pick, D., \& Roche, M. (2017). Mindfulness as a personal resource to reduce work stress in the job demands-resources model. Stress and Health, 33(4), 426436.

Government of Malaysia (2006). Ninth Malaysia Plan 2006-2010. Planning Economy Unit. Prime Minister Department, Putrajaya, 2006.

Hair, J. F., Black, W. C., Babin, B. J. \& Anderson, R. E. (2010). Multivariate data analysis ( $7^{\text {th }}$ edn). Pearson Prentice Hall.

Hoboubi, N., Choobineh, A., Ghanavati, F. K., Keshavarzi, S., \& Hosseini, A. A. (2017). The

Impact of Job Stress and Job Satisfaction on Workforce Productivity in an Iranian Petrochemical Industry. Safety and Health at Work, 8(1), 67-71. https://doi.org/10.1016/j.shaw.2016.07.002

Ibrahim, M., \& Brobbey, V. A. (2015). Impact of motivation on employee performance the case of some selected micro finance companies in Ghana. International Journal of Economics, Commerce and Management, 3(11), 1218-1236.

Jalilian, H., Shouroki, F. K., Azmoon, H., Rostamabadi, A., \& Choobineh, A. (2019). Relationship between job stress and fatigue based on job demand-control-support model in hospital nurses. International journal of preventive medicine, 10.

Johari, R. J., Ridzoan, N. S., \& Zarefar, A. (2019). The Influence of Work Overload, Time Pressure and Social Influence Pressure on Auditorsi ${ }^{-}$Job Performance. International Journal of Financial Research, 10(3), 88-106.

Kamery, R. H. (2004). Motivational Techniques for Positive Reinforcement: A Review. Allied Academies International Conference. 8 (2), 91-96.

Karasek, R. (1979). Job Demands, Job Decicion Latitude, and Mental Strain: Implications for Job Redesign. Administrative Science Quarterly, 24(285), 308.

Karasek, R., \& Theorell, T. (1990). Healthy work: stress, productivity, and the reconstruction of working life. New York, NY: Basic Books.

Khan, S., \& Mashikhi, L. S. (2017). Impact of teamwork on employee's performance. International Journal of Education and Social Science, 4(11), 14-22.

Khair, H. (2017). Manajemen Kompensasi. Medan: Madenatera.

Kholed, S. N. S., Maon, S. N., \& Hassan, N. M. (2021). Reliability and validity of the interprofessional collaboration practice instrument. Journal of Interprofessional Education \& Practice, 100450.

Kokt, D., \& Ramarumo, R. (2015). Impact of organisational culture on job stress and burnout in graded accommodation establishments in the Free State province, South Africa. International Journal of Contemporary Hospitality Management, 1198-1213. 
Koopmans, L., Bernaards, C. M., Hildebrandt, V. H., Van Buuren, S., Van der Beek, A. J., \& De Vet, H. C. (2014). Improving the individual work performance questionnaire using rasch analysis. Journal of applied measurement, 15(2), 160-175.

Leroy, S., \& Glomb, T. M. (2018). Tasks interrupted: How anticipating time pressure on resumption of an interrupted task causes attention residue and low performance on interrupting tasks and how a "ready-to-resume" plan mitigates the effects. Organization Science, 29(3), 380-397.

Lin, L. H., \& Chen, W. (2013). A preliminary study on time pressure and procrastination in undergraduate industrial design students. In Consilience and Innovation in Design, 5th International Congress of IASDR 2013 (Vol. 2, pp. 1812-1823).

Linz, S. J., Good, L. K., \& Huddleston, P. (2006). Worker morale in Russia: an exploratory study. Journal of Managerial Psychology, 21 (5), 415-437

Li, C., Naz, S., Khan, M. A. S., Kusi, B., \& Murad, M. (2019). An empirical investigation on the relationship between a high-performance work system and employee performance: measuring a mediation model through partial least squares-structural equation modeling. Psychology research and behavior management, 12, 397.

Nunnally, J.C. (1978). Psychometric theory. 2nd Edition, McGraw-Hill, New York.

Nunnally, J.C. \& Bernstein, I.H. (1994) The Assessment of Reliability. Psychometric Theory, 3, 248-292.

Omar, M. K., Mohd, I. H., \& Ariffin, M. S. (2015). Workload, role conflict and work-life balance among employees of an enforcement agency in Malaysia. International Journal of Business, Economics and Law, 8(2), 52-57.

Omar, S. N. Z., Mohamad, M., Basarud-din, S. K., \& Abu Bakar, A. (2019). Faktor-faktor yang mempengaruhi kepuasan kerja dalam kalangan pekerja sektor swasta.

Ouakouak, M. L., Zaitouni, M. G., \& Arya, B. (2020). Ethical leadership, emotional leadership, and quitting intentions in public organizations: does employee motivation play a role? Leadership \& organization development journal.

Prajogo, D. I. (2007). The relationship between competitive strategies and product quality. Industrial Management and Data Systems, 107(1), 69-83.

Prange, C., \& Pinho, J. C. (2017). How personal and organizational drivers' impact on SME international performance: The mediating role of organizational innovation. International Business Review, 26(6), 1114-1123.

Raby, M., \& Wickens, C. D. (1994). Strategic workload management and decision biases in aviation. The International Journal of Aviation Psychology, 4 (3), 211-240.

Ramos-Villagrasa, P. J., Barrada, J. R., Fernández-del-Río, E., \& Koopmans, L. (2019). Assessing job performance using brief self-report scales: The case of the individual work performance questionnaire (No. ART-2019-121928).

Rodriguez, J., \& Walters, K. (2017). The importance of training and development in employee performance and evaluation. Worldwide Journal of Multidisciplinary Research and Development, 3(10), 206-212.

Rusmiati, E., Harjadi, D., \& Fitriani, L. K. (2021). Analysis of The Impact of Risk and Workload on Motivation and Impact on Employee Performance. International Journal of Economics, Business and Accounting Research (IJEBAR), 5(2). Sekaran U., \& Bougie R., (2016). Research Methods for Business: A Skill Building Approach, $7^{\text {th }}$ Edition. www.wiley.com. 
Ryari, H., Alavi, S., \& Wieseke, J. (2021). Drown or blossom? the impact of perceived chronic time pressure on retail salespeople's performance and customer-salesperson relationships. Journal of Retailing, 97(2), 217-237.

Sijbom, R. B., Anseel, F., Crommelinck, M., De Beuckelaer, A., \& De Stobbeleir, K. E. (2018). Why seeking feedback from diverse sources may not be sufficient for stimulating creativity: The role of performance dynamism and creative time pressure. Journal of Organizational Behavior, 39(3), 355-368

Silitonga, E. W., \& Sadeli, J. (2020). Factors contributing to employee performance. In Contemporary Research on Business and Management: Proceedings of the International Seminar of Contemporary Research on Business and Management (ISCRBM 2019), 27-29 November, 2019, Jakarta, Indonesia (p. 15). CRC Press.

Shah, F. A. (2003). Role stress in the Indian industry: A study of banking organisations. Indian Journal of Industrial Relations, 281-296.

Tabassum, S., Siddiqui, I. H., \& Shabbir, M. H. (2021). Impact of physical workspace environment factors on employee performance and turnover intention. International Journal of Management (IJM), 12(1).

Universiti Teknologi MARA. (2021). Pekeliling Pelaksanaan Pengoperasian Universiti Teknologi MARA Semasa Perintah Kawalan Pergerakan (PKP), Perintah Kawalan Pergerakan Bersyarat (PKPB) dan Perintah Kawalan Pergerakan Pemulihan (PKPP), 1 (2021).

Vaananen, A., \& Toivanen, M. (2018). The challenge of tied autonomy for traditional work stress models.

Wijaya, I. A., \& Yulyona, M. T. (2017). Does Complexity Audit Task, Time Deadline Pressure, Obedience Pressure, and Information System Expertise Improve Audit Quality? International Journal of Economics and Financial Issues, 7(3), 398-403.

Wilhelm, R., Engblom, J., Ermedahl, A., Holsti, N., Thesing, S., Whalley, D., \& Stenström, P. (2008). The worst-case execution-time problem-overview of methods and survey of tools. ACM Transactions on Embedded Computing Systems (TECS), 7(3), 1-53.

Wirth, B. E., \& Carbon, C. C. (2017). An easy game for frauds? Effects of professional experience and time pressure on passport-matching performance. Journal of experimental psychology: applied, 23(2), 138.

Wong, W. P., \& Wong, K. Y. (2007). Supply chain performance measurement system using DEA modelling. Industrial Management and Data Systems, 107(3), 361-81. 